\title{
Tampilan Bobot Badan, Ukuran Linear Tubuh, Serta Umur dan Skor Kondisi Tubuh Ternak Sapi Bali yang Dipotong pada RPH Kota Kefamenanu
}

\author{
Sergius Pikan ${ }^{\mathrm{a}}$, Paulus Klau Tahuk ${ }^{\mathrm{b}}$, dan Hilarius Yosef Sikone \\ ${ }^{a}$ Fakultas Pertanian, Universitas Timor, Kefamenanu, TTU - NTT, Indonesia, Email. \\ ${ }^{b}$ Fakultas Pertanian, Universitas Timor, Kefamenanu, TTU - NTT, Indonesia, Email; paulklau@yahoo.co.id \\ ${ }^{c}$ Fakultas Pertanian, Universitas Timor, Kefamenanu, TTU - NTT, Indonesia, Email; yosefsikone@gmail.com
}

\section{Article Info}

\section{Article history:}

Received 6 Maret 2018

Received in revised form 11 April 2018

Accepted 20 April 2018

\section{DOI}

https://doi.org/10.32938/ja.v3i2.288

Keywords:

Bobot Badan

Ukuran Linear Tubuh

Skor Kondisi Tubuh

Umur

\begin{abstract}
Abstrak
Penelitian ini dilaksanakan di RPH Kota Kefamenanu Kabupaten TTU dari tanggal 28 November 2017 sampai dengan tanggal 3 Februar 2018. Penelitian ini bertujuan untuk mengetahui tampilan bobot badan, ukuran linear tubuh, serta umur dan skor kondisi tubuh ternak Sapi Bali yang dipotong pada RPH Kota Kefamenanu. Dalam penelitian ini digunakan 45 ekor ternak Sapi Betina pada umur 4,5 tahun dan 5,5 tahun. Metode yang digunakan dalam penelitian ini adalah metode pengukuran langsung pada ternak sapi yang dipotong di RPH Kefamenanu. Hasil penelitian menunjukkan bahwa rata-rata bobot badan pada umur 4,5 tahun sebesar 198,32 kg, panjang badan $96,32 \mathrm{~cm}$, lingkar dada 146,59 cm, tinggi pundak $109,18 \mathrm{~cm}$ dan skor kondisi tubuh sebesar 4,32. Ternak umur 5,5 tahun memiliki rata-rata bobot badan $214,22 \mathrm{~kg}$, panjang badan $98,22 \mathrm{~cm}$, lingkar dada $149,13 \mathrm{~cm}$, tinggi pundak 109,83 cm dan skor kondisi tubuh sebesar 4,00. Nilai koefisien korelasi pada tiap umur memiliki keeratan yang berbeda-beda. Keeratan antara lingkar dada dengan bobot badan pada umur 4,5 sebesar (r) 0,735. Keeratan hubungan antara tinggi pundak dengan bobot badan pada umur 4,5 sebesar (r) 0,445. Keeratan antara skor kondisi tubuh dengan bobot badan pada pada umur 5,5 tahun sebesar (r) 0,59. Secara keseluruhan lingkar dada dan bobot badan memiliki nilai korelasi lebih tinggi sebesar (r) 0,735. Dapat disimpulkan bahwa terdapat variasi bobot badan dan ukuran linear tubuh serta skor kondisi tubuh induk Sapi Bali yang dipotong pada RPH Kota Kefamenanu. Secara keseluruhan, lingkar dada memiliki keeratan yang lebih baik dengan bobot badan bila dibandingkan dengan tinggi pundak dan panjang badan
\end{abstract}

\section{Pendahuluan}

Sapi Bali merupakan sapi asli Indonesia, berasal dari hasil domestikasi banteng (Batan, 2006). Sapi Bali juga merupakan salah satu aset nasional yang cukup potensial untuk dikembangkan ke seluruh wilayah Indonesia, hal in terjadi karena breed (bangsa) ini, memiliki beberapa keunggulan antara lain tingkat kesuburan yang tinggi, sebagai sapi pekerja yang baik dan efisien, dapa memanfaatkan hijauan yang kurang bergizi, presentasi karkas yang tinggi, dan daya adaptasi yang tinggi terhadap lingkungan serta memberikan kontribus dalam pemenuhan daging nasional karena memiliki sumber utama protein yang tinggi. Untuk meningkatkan produktifitas ternak sapi dalam rangka memenuh kebutuhan protein masyarakat, salah satu usaha diperlukan informasi mengenai bobot hidup sapi. Bobot badan merupakan indikator penting dalam keberhasilan manajemen peternakan, untuk memprediksi bobot badan sapi, pada umumnya berdasarkan ukuran linear tubuh ternak (Kadarsih, 2003).

Bobot badan seekor sapi hanya dapat diketahui secara tepat melalui cara penimbangan, namun dalam situasi dan kondisi tertentu, terutama pada kondis peternakan rakyat, jarang atau tidak tersedia alat timbangan ternak sapi. Oleh karena itu dibutuhkan cara lain yang dianggap praktis untuk mengukur bobo badan seekor ternak dengan mengukur lingkar dada yang dilakukan dengan cara melingkarkan pita ukur pada bagian di belakang bahu $(\mathrm{cm})$, panjang badan diukur dengan pita ukur dari ujung samping tulang bahu sampai dengan ujung tulang duduk $(\mathrm{cm})$ dan tinggi pundak dengan mengukur jarak tegak lurus dar tanah sampai dengan puncak gumba di belakang punuk (cm). Erwinda (2012) menyatakan bahwa, ukuran-ukuran tubuh (bobot badan, panjang badan, tingg pundak dan lingkar dada) dipengaruhi oleh umur. Hal ini didukung oleh pernyataan Soeparno, (2005), bahwa umur sangat berpengaruh terhadap pertumbuhan badan sapi yang berpengaruh juga terhadap bobot sapi Pertumbuhan dari tubuh hewan mempunyai arti penting dalam suatu proses produksi, karena produksi yang tinggi dapat dicapai dengan adanya pertumbuhan yang cepat dari hewan tersebut. Umur Sapi Bali dapat diketahui dengan melihat gigi serinya.

Kabupaten Timor Tengah Utara (TTU) merupakan salah satu pusa pengembangan ternak khususnya Sapi Bali di Pulau Timor, yang memiliki potensi ternak yang sangat potensial untuk dikembangkan dalam mendukung peningkatan/penguatan ekonomi daerah maupun masyarakat. Sapi potong yan merupakan komoditas ternak andalan Kabupaten TTU dalam hal ini Sapi Bali, belakangan ini populasinya cenderung menurun dan sangat memprihatinkan karena jumlahnya masih jauh dari target yang diperlukan konsumen. Faktor yang menyebabkan jumlah produksi daging masih rendah diantaranya produktifitas sapi yang semakin menurun, pemotongan ternak yang masih produktif, perdagangan bibit sapi unggul yang kurang terkontrol baik, pola pemeliharaan yang sebagian besar dipelihara oleh masyarakat pedesaan secara tradisional, dan tingkat pendapatan masyarakat yang menurun mengakibatkan ternak yang masih produktif dijual untuk memenuhi kebutuhan hidup sehari-hari.

\section{Metode}

Penelitian ini telah dilaksanakan di RPH Kota Kefamenanu Kabupaten Timor Tengah Utara selama 2 bulan, mulai dari tanggal 28 November 2017 sampai dengan tanggal 3 Februari 2018. Metode yang digunakan dalam penelitian ini adalah metode pengukuran langsung pada ternak sapi yan dipotong di RPH Kefamenanu sebanyak 1-2 ekor/hari dan wawancara untuk memperoleh data pendukung dengan pengelola atau petugas RPH. Data yang digunakan dalam penelitian ini adalah data sekunder dan primer. Data primer berasal dari hasil-hasil wawancara dan catatan pengukuran panjang badan, lingkar dada dan tinggi pundak, serta penentuan kondisi tubuh ternak secara langsung di lapangan. Bobot badan diperoleh dari hasil penimbangan bobot badan yang dilakukan secara langsung dengan timbangan digital. Data sekunder diperoleh dari laporan pemotongan hewan yang dipublikasikan oleh dinas peternakan.

Tabel 1. Penentuan Umur Berdasarkan Susunan Gigi pada Sapi Bali.

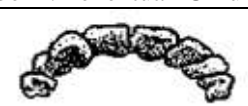
Umur 1 bulan terdapat dua atau lebih gigi seri sementara, dalam bulan pertama gigi seri sementara muncul semuanya

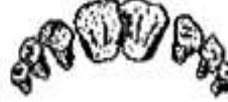

Berumur antara 1-2 tahun, pasangan gigi seri sementara (I1) digantikan oleh gigi permanen (I1) Dalam 2 tahun gigi permanen sentral (I1) mencapai pertumbuhan penuh.

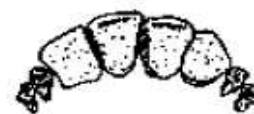

Berumur 2-2,5 tahun, pasangan gigi seri intermedial (I2) digantikan oleh gigi permanen intermedial (I2). Pertumbuhan penuh biasanya umur 3 tahun

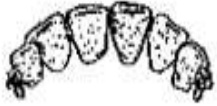

Berumur 3-3,5 tahun, pasangan gigi seri intermedia kedua atau lateral (I3) digantikan oleh gigi permanen intermedial kedua (I3). Intermedial mulai mengalami keausan umur 4 tahun.

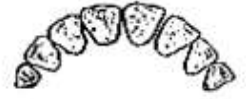

Berumur 4-4,5 tahun, gigi sudut (I4) digantikan oleh gigi permanen (I4). Pada umur 5 tahun gigi sudut biasanya telah tumbuh sempurna

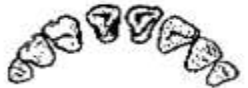

Berumur 5-6 tahun, gigi permanen (I1) rata, pasangan intermediet sebagian rata, dan gigi sudut mula terlihat alus.

Berumur 7-10 tahun, pada umur 7 atau 8 tahun I1 terlihat keausan yang nyata, dan pada umur 10 tahun I4 baru terlihat keausan yang nyata.

Berumur 12 tahun, lengkungan sudut tadak terlihat dan membentuk segitiga yang jelas yang menandakan bertambahnya usia.

\section{Sumber: Torell $d k k .(2003)$.}

Variabel yang diukur yaitu ukuran tubuh yang terdiri dari bobot badan, lingkar dada, tinggi pundak, panjang badan. Semua pengukuran terhadap ukuran tubuh tersebut dilakukan sebanyak 3 kali untuk menghindari kesalahan pengukuran dan hasil akhir merupakan rataan dari pengukuran tersebut Pengukuran ukuran tubuh dilakukan dengan cara :

a. Bobot badan diukur menggunakan timbangan digital. Menyiapkan sesuai dengan penggunaan, kemudian sapi dinaikkan ke atas timbangan. Nilai yang tertera pada monitor merupakan bobot badan sapi tersebut

b. Lingkar dada diukur dengan menggunakan pita ukur, melingkar tepat dibelakang scapula.

c. Tinggi pundak diukur dengan menggunakan tongkat ukur, dari bagian tertinggi pundak melewati bagian belakang scapula, tegak lurus dengan tanah

d. Panjang badan diukur dengan pita ukur dari ujung samping tulang bahu sampai dengan ujung tulang duduk. 
e. Jenis kelamin ternak berdasarkan pengamatan.

f. Skor kondisi yaitu penilaian dengan angka interval antara 1-5 untuk menentukan tingkat kegemukan seekor sapi menurut Rutter $d k k$. (2000).

g. Umur ternak diestimasi berdasarkan susunan gigi sesuai dengan Tabel 1.

Data yang sudah terkumpul dianalisis secara deskriptif dengan cara menggunakan analisis statistik untuk menghitung rata-rata, standar deviasi dan koefisiensi keragaman bobot badan, ukuran linear tubuh, dan skor kondisi tubuh menurut (Sugiono, 2000). Untuk mengetahui hubungan bobot badan, ukuran linear tubuh dan skor kondisi tubuh ternak Sapi Bali digunakan metode korelasi pearson menurut (Akdon, 2013).

\section{Hasil dan Pembahasan}

\subsection{Gambaran Umum Rumah Potong Hewan Kota Kefamenanu}

Rumah Pemotongan Hewan (RPH) Kota Kefamenanu sebagai salah satu RPH yang ada di TTU, didirikan pada tahun 1975 dengan luas $180 \mathrm{~m}^{2}$ dan dikategorikan sebagai RPH tipe I. Secara geografis RPH Kefamenanu terletak di Kelurahan Kefamenanu Selatan, sebelah Timur berbatasan dengan RT.02 Kota Baru, sebelah Barat berbatasan dengan Jalan Eltari, sebelah Utara berbatasan dengan RT.03 Kota Baru, sebelah Selatan berbatasan dengan sungai Dalehi (Dinas Peternakan Kab. TTU, 2016).

Pemotongan hewan di RPH Kota Kefamenanu dilakukan setiap har dengan waktu pemotongan dimulai antara jam 03.00 dini hari sampai pukul 06.00 WITA. Proses pemotongan yang diterapkan pada RPH ini adalah sistem pemotongan tradisional yang dilakukan dengan merebahkan sapi mengunakan tali tambang, kepala diletakan di atas lantai dan dihadapkan arah timur untuk menjaga kehalalan pemotongan sapi karena konsumen pada umumnya beragama Islam. Leher dipotong dengan pisau potong yang tajam pada rahang bawah sehingga oesophagus, Vena jugularis, Arteri carotis dan trachea dapat terpotong dengan sempurna sehingga mendapatkan pendarahan yang sempurna pula. Sapi yang akan disembelih di RPH Kota Kefamenanu adalah milik pengusaha yang dibeli di masyarakat setempat. Jumlah sapi yang akan dipotong di RPH rata-rata 5-10 ekor setiap hari atau antara 100-300 kg daging sesuai permintaan pengusaha dan permintaan pasar.

Berdasarkan hasil wawancara dengan pengusaha di lapangan, kebanyakan sapi dibeli di daerah Insana dan Bikomi kemailarena memiliki bobot badan yang baik dan harganya relatif murah. Jenis ternak yang dibeli pengusaha adalah ternak jantan dan betina yang berumur 3-10 tahun dengan kondisi gemuk dan layak untuk disembelih, pengusaha biasanya membeli sapi dengan menduga bobot badan saja karena dalam situasi dan kondisi tertentu, terutama pada kondisi peternakan rakyat, jarang atau tidak tersedia alat timbangan ternak sapi. Sesuai pengamatan langsung di lapangan rata-rata sapi yang dibeli pengusaha untuk disembelih di RPH Kota Kefamenanu berjenis kelamin betina karena memiliki persentase perlemakan yang tinggi dibandingkan sapi jantan. Selain itu diakibatkan karena: (1) harga sapi betina lebih murah dibandingkan sapi jantan dengan ukuran sama, (2) rendahnya kesadaran masyarakat untuk menyelamatkan populasi sapi bali, (3) peternak akan menjual sapi betina produktif karena alasan ekonomi, (4) pengawasan dari pemerintah sangat lemah, dan (5) mahalnya harga sapi jantan diluar daerah sehingga mendorong peternak menjual ternaknya keluar daerah (Harmini dkk., 2011). Tingginya pemotongan Sapi Bali betina usia produktif menyebabkan laju pertambahan populasi menjadi lambat, rendahnya tingkat kelahiran yang tidak mampu mengimbangi tingkat pemotongan dan kematian. Jika keadaan ini terus menerus dibiarkan maka dikhawatirkan dapat mengancam kelestarian Sapi Bali di masa depan dan akan terjadi pengurasan sumber daya ternak.

\subsection{Rata-Rata Ukuran Linear Tubuh dan Skor Kondisi Tubuh Ternak} Sapi Bali di RPH Kota Kefamenanu.

Ukuran-ukuran tubuh ternak yang diukur pada penelitian ini adalah panjang badan, lingkar dada, tinggi pundak dan bobot badan serta skor kondisi tubuh yang dilakukan melalui pengukuran langsung di lapangan. Ukuran-ukuran tubuh Sapi Bali pada penelitian ini dikelompokan berdasarkan sampel yang dibutuhkan yaitu Sapi Bali dengan kondisi umur 4-5 sampai 5-6 tahun. Rata-rata ukuran linear tubuh Sapi Bali di RPH Kota Kefamenanu dapat dilihat pada Tabel 2 .

Tabel 2. Ukuran tubuh dan skor kondisi tubuh Sapi Bali pada umur 4,5 tahun dan 5,5 tahun yang dipotong pada RPH Kota Kefamenanu.

\begin{tabular}{ccccccc}
\hline \multirow{2}{*}{ Umur } & & $\begin{array}{c}\text { Bobot } \\
\text { Badan } \\
(\mathrm{Kg})\end{array}$ & $\begin{array}{c}\text { Panjang Badan } \\
(\mathrm{Cm})\end{array}$ & $\begin{array}{c}\text { Lingkar } \\
\text { Dada } \\
(\mathrm{Cm})\end{array}$ & $\begin{array}{c}\text { Tinggi } \\
\text { Pundak } \\
(\mathrm{Cm})\end{array}$ & $\begin{array}{c}\text { Skor Kondisi } \\
\text { Tubuh }\end{array}$ \\
\hline \multirow{2}{*}{4,5} & Rata-Rata & 198,32 & 96,32 & 146,59 & 109,18 & 4,32 \\
Tahun & SD & 36,41 & 4,42 & 8,26 & 4,75 & 0,84 \\
& KV $(\%)$ & 18,36 & 4,59 & 5,63 & 4,35 & 19,41 \\
\hline \multirow{2}{*}{5,5} & Rata-Rata & 214,22 & 98,22 & 149,13 & 109,83 & 4,00 \\
Tahun & SD & 33,30 & 5,72 & 6,70 & 4,47 & 0,91 \\
& KV $(\%)$ & 15,54 & 5,82 & 4,49 & 4,07 & 22,63 \\
\hline
\end{tabular}

Hasil penelitian pada Tabel 2. menunjukkan bahwa bobot badan umur 4,5 tahun adalah minimum $140 \mathrm{~kg}$ dan maksimum $253 \mathrm{~kg}$ dengan rata-rata 198,32 $\mathrm{kg}$, sedangkan pada umur 5,5 tahun bobot badan minimum $137 \mathrm{~kg}$ dan maksimum $251 \mathrm{~kg}$ dengan rata-rata $214,22 \mathrm{~kg}$. Bobot badan yang yang diperoleh pada penelitian ini masih relatif sama jika dibandingkan dengan hasil peneltian Ni'am dkk. (2012) sebesar 199,70 kg, 211,45 kg.

Panjang badan ternak pada umur 4,5 tahun adalah minimum $88 \mathrm{~cm}$ dan maksimum $103 \mathrm{~cm}$ dengan rara-rata $96,32 \mathrm{~cm}$; dan pada umur 5,5 tahun minimum $89 \mathrm{~cm}$ dan maksimum $110 \mathrm{~cm}$ dengan hasil rara-rata 98,22 cm. Panjang badan yang diperoleh pada penelitian ini masih di bawah rata-rata jika dibandingkan dengan hasil pengukuran Ni'am $d k k$. (2012) sebesar 105-106,9 cm Ukuran panjang badan meningkat sesuai dengan pertumbuhan dan pertambahan bobot badan atau ukuran tubuh sesuai dengan umur. Umur ternak berperan penting dalam perubahan dimensi tubuhnya. Ternak yang mendapat perlakuan dan manajemen pemeliharaan yang baik dari usia muda maka perubahan atau pertambahan dimensi tubuhnya akan bagus (Siregar, 2008).

Lingkar dada pada umur 4,5 tahun adalah minimum $129 \mathrm{~cm}$ dan maksimal $160 \mathrm{~cm}$ dengan rata-rata $146,59 \mathrm{~cm}$; dan pada umur 5,5 tahun minimum $132 \mathrm{~cm}$ dan maksimal $159 \mathrm{~cm}$ dengan rata-rata $149,13 \mathrm{~cm}$. Rata-rata lingkar dada yang diperoleh pada penelitian ini masih di atas rata-rata lingkar dada yang dilaporkan oleh Ni'am dkk. (2012) sebesar 141,35-142,75 cm. Hal ini menunjukkan bahwa dengan bertambahnya bobot badan maka bertambah pula ukuran lingkar dada, begitu pula sebaliknya, dengan menurunnya ukuran bobot badan, maka menurun juga ukuran lingkar dadanya.

Tinggi pundak ternak pada umur 4,5 tahun adalah minimum $100 \mathrm{~cm}$ dan maksimum $118 \mathrm{~cm}$ dengan rata-rata $109,18 \mathrm{~cm}$, dan pada umur 5,5 tahun minimum $97 \mathrm{~cm}$ dan maksimum $115 \mathrm{~cm}$ dengan rata-rata 109,83 cm. Tinggi pundak yang diperoleh pada penelitian ini masih di bawah rata-rata jika dibandingkan dengan hasil pengukuran Ni'am $d k k$. (2012) sebesar 109,8-111,5 $\mathrm{cm}$. Hal ini menunjukkan bahwa perubahan bentuk atau ukuran seekor ternak dipengaruhi oleh pakan yang menjadi salah satu tuntutan utama, dengan adanya pakan tubuh hewan akan mampu bertahan hidup dan kesehatan terjamin. Pemberian pakan kepada ternak sapi potong bertujuan untuk memenuhi kebutuhan pokok hidup dan perawatan tubuh serta keperluan berproduksi.

Skor kondisi tubuh (Tabel 2.) menunjukkan bahwa terdapat perbedaan skor kondisi tubuh ternak Sapi Bali dimana pada umur ternak 4,5 tahun memiliki skor kondisi tubuh yang lebih baik dengan nilai minimum 2 dan maksimum 5 dengan rata-rata 4,32, sedangkan pada umur 5,5 tahun memiliki nilai minimum 2 dan maksimum 5 dengan rata-rata 4,00. Perbedaan ukuran skor kondisi tubuh diduga disebabkan oleh faktor genetik ternak yang berbeda sehingga mengakibatkan adanya perbedaan dalam tingkat pertumbuhan dan bobot dewasa yang dicapai, faktor pemeliharaan yang pada umumya dipelihara oleh masyarakat pedesaan secara tradisional serta manajemen ternak yang rendah dan kurang terarah, dimana peternak belum memperhatikan mutu pakan, ketersediaan pakan, tata cara pemeliharaan, dan penyakit sehingga pola pertumbuhan ternak pada umur pertumbuhan kurang optimum. Hal ini sesuai laporan Sudarmono \& Bambang (2008) yang menyatakan bahwa kekurangan pakan merupakan kendala besar dalam proses pertumbuhan. Apabila dalam pakan tersebut zat-zat pakan untuk pertumbuhan sangat kurang tersedia seperti protein, vitamin dan mineral maka hal ini dapat menyebabkan pertumbuhan tubuh ternak tidak maksimal. Hal yang sama juga disampaikan Sugeng (2003) yang menyatakan bahwa adanya perbedaan ukuran tubuh suatu ternak dipengaruhi oleh adanya beberapa faktor diantaranya faktor pengaruh bangsa sapi, pengaruh umur sapi, pengaruh jenis kelamin sapi, pengaruh pakan yang diberikan pada ternak sapi, pengaruh suhu serta iklim lingkungan di sekitar habitat sapi.

\subsection{Korelasi Bobot Badan Dengan Ukuran Linear Tubuh Ternak Sapi Bali Pada Umur 4,5 Tahun dan 5,5 Tahun}

Hasil analisis korelasi antara bobot badan dengan linear tubuh ternak Sapi Bali betina pada umur 4,5 tahun dan 5,5 tahun secara parsial menghasilkan hubungan yang signifikan dan tidak signifikan. Adapun hasil analisis korelasi dapat dilihat pada Tabel 3

Tabel.3. Korelasi antara bobot dengan ukuran linear tubuh ternak Sapi Bali pada umur 4,5 tahun dan 5,5 tahun yang dipotong pada RPH Kota Kefamenanu.

\begin{tabular}{|c|c|c|c|c|c|}
\hline Umur & & & $\begin{array}{c}\text { Panjang } \\
\text { Badan }(\mathrm{Cm})\end{array}$ & $\begin{array}{c}\text { Lingkar } \\
\operatorname{Dada}(\mathrm{Cm})\end{array}$ & $\begin{array}{c}\text { Tinggi Pundak } \\
(\mathrm{Cm})\end{array}$ \\
\hline 4,5 & Bobot & $\begin{array}{c}\text { Pearson } \\
\text { Correlation }\end{array}$ & 0,185 & $0,735^{* *} *$ & $0,445^{*}$ \\
\hline Tahun & Badan & $\begin{array}{c}\text { Sig. (2-talled) } \\
\mathrm{N}\end{array}$ & $\begin{array}{c}0,410 \\
22\end{array}$ & $\begin{array}{c}0,000 \\
22\end{array}$ & $\begin{array}{c}0,038 \\
22\end{array}$ \\
\hline 5,5 & Bobot & $\begin{array}{c}\text { Pearson } \\
\text { Correlation }\end{array}$ & 0,326 & $0,670 * *$ & 0,338 \\
\hline Tahun & Badan & $\begin{array}{c}\text { Sig. (2-talled) } \\
\mathrm{N}\end{array}$ & $\begin{array}{c}0,129 \\
23\end{array}$ & $\begin{array}{c}0,000 \\
23\end{array}$ & $\begin{array}{c}0,114 \\
23\end{array}$ \\
\hline
\end{tabular}

\subsection{Korelasi Bobot Badan Dengan Panjang Badan}

Pada tabel di atas terlihat bahwa hasil analisis korelasi antara bobot badan dengan panjang badan pada umur 4,5 tahun menghasilkan nilai korelasi (r) 0,185 ; dengan tingkat signifikan 0,410 dan pada umur 5,5 tahun menghasilkan nilai korelasi (r) 0,326; dengan tingkat signifikan 0,129. Hal ini mengindikasikan bahwa hubungan antara bobot badan dengan panjang badan pada umur 4,5 tahun dan 5,5 tahun memiliki hubungan yang lemah atau tidak signifikan karena tingkat pertumbuhan tulang pada ternak sudah terhenti. Pertumbuhan bukan hanya otot 
dan lemak yang bertambah tetapi struktur penyusun tubuh seperti tulang pun juga ikut bertambah. Djagra $d k k$. (2002), menyatakan bahwa pertumbuhan tulang dapat mempengaruhi panjang badan dan bobot badan sedangkan pertumbuhan daging mempengaruhi lingkar dada. Pertumbuhan tulang akan meningkat pada laju pertumbuhan awal, kemudian akan diikuti dengan perkembangan dan terakhir dengan adanya kandungan energi pakan yang diberikan, maka lemak akan mengalami peningkatan pesat.

Hasil penelitian ini tidak sejalan dengan laporan Ni'am $d k k$. (2012) yang memperoleh korelasi yang sangat kuat dan positif antara bobot badan dan panjang badan dengan nilai korelasi (r) 0,78 dan 0,76 . Perbedaan hasil penelitian tersebut diduga karena perbedaan pola pemeliharaan yang sudah intensif, dimana pemberian pakan, dan perawatan yang sudah terkontrol baik. Sebaliknya pada penelitian ini tidak memiliki korelasi yang positif karena pola pemeliharaan yang masih tradisional dan tidak terkontrol perkembangan ternak sehingga membuka peluang besar terjadinya inbriding (kawin saudara), pemberian pakan pada ternak juga tidak memperhatikan kecukupan nutrisi dan jumlah dosis obat yang diberikan kepada ternak.

Menurut Sugeng, (2003), adanya perbedaan ukuran sifat kuantitatif suatu ternak dipengaruhi oleh adanya beberapa faktor yaitu diantaranya faktor pengaruh bangsa sapi, umur sapi, jenis kelamin pengaruh pakan yang diberikan kepada ternak sapi dan pengaruh suhu serta iklim lingkungan di sekitar habitat sapi. Faktor pakan sangat penting dalam pemenuhan kebutuhan pertumbuhan Kekurangan pakan merupakan kendala besar dalam proses pertumbuhan, terlebih dalam pakan yang terdapat banyak zat-zat pakan untuk pertumbuhan tersedia sangat kurang seperti protein, vitamin dan mineral. Kondisi ini dapat menyebabkan ternak tidak dapat bertumbuh dengan baik. Sapi yang dewasa membutuhkan protein untuk menggantikan jaringan yang telah rusak dan untuk memproduksi atau membentuk daging (Sudarmono \& Bambang, 2008).

\subsection{Hubungan Bobot Badan Dengan Lingkar Dada}

Hasil analisis korelasi bobot badan terhadap lingkar dada pada umur 4,5 tahun menghasilkan hubungan yang sangat signifikan dengan nilai korelasi $(\mathrm{r})$ 0,735 ; tingkat signifikan 0,000 dan pada umur 5,5 tahun menghasilkan hubungan yang sangat signifikan juga dengan nilai korelasi (r) 0,670 dan tingkat signifikan 0,000. Hal ini menunjukkan bahwa ada hubungan yang sangat kuat dan positif antara dua variabel tersebut. Hasil penelitian ini tidak berbeda jauh dengan laporan penelitian Ni'am $d k k$. (2012) yang memperoleh nilai korelasi yang kuat sebesar (r) 0,84 dan 0,83. Korelasi antara bobot badan dengan lingkar dada dapat menghasilkan hubungan positif antara dua variabel. Hal ini menunjukan bahwa lingkar dada pada setiap umur memiliki keeratan hubungan yang lebih baik dengan bobot badan jika dibandingkan dengan panjang badan dan tinggi pundak. Pengukuran lingkar dada mudah dimengerti karena lingkar dada menunjukkan volume. Seperti halnya pengukuran volume, secara matematis diperoleh dengan mengalikan luas dan tinggi. Bila diibaratkan luas maka lingkar dada menggambarkan luas, sedangkan panjang badan menggambarkan tinggi. Secara praktis pengukuran lingkar dada lebih mudah, dibandingkan dengan pengukuran lainnya yang membutuhkan tongkat ukur dengan pengukuran yang tegak lurus, sedangkan pengukuran lingkar dada hanya menggunakan pita ukur dan melingkarkannya ke dada.

Menurut Yusuf (2004), secara fisiologis lingkar dada mempunyai pengaruh yang besar terhadap bobot badan karena dalam rongga dada terdapat organ-organ seperti jantung dan paru-paru, begitu juga dengan pertumbuhan panjang badan tubuh ternak. Pertumbuhan tubuh dan organ-organ tersebut akan tumbuh dan mengalami pembesaran sejalan dengan perumbuhan ternak. Di samping itu, pertambahan bobot badan juga dipengaruhi oleh penimbunan lemak. Dijelaskan bahwa tulang-tulang dalam tubuh ternak (termasuk diantaranya tulang kaki) ketika mengalami pertumbuhan optimum maka pertumbuhannya akan terhenti, sedangkan tulang rusuk masih dapat tumbuh dan berkembang karena merupakan tulang yang pertumbuhannya paling akhir, sehingga dapat menambah panjang ukuran lingkar dada. Lingkar dada pada sapi yang berumur dewasa tubuh dapat digunakan sebagai peramal bobot badan dengan nilai determinasi sebesar 22,2\% (Kadarsih, 2003).

\subsection{Korelasi Bobot Badan Dengan Tinggi Pundak}

Hasil analisis korelasi antara bobot badan dengan tinggi pundak pada umur 4,5 tahun menghasilkan hubungan yang signifikan dengan nilai korelasi (r) 0,445 dan tingkat signifikan 0,038. Hal ini menunjukkan bahwa terdapat hubungan positif antara tinggi pundak dengan bobot badan yang semakin erat seiring dengan bertambahnya umur; sedangkan pada umur 5,5 tahun menghasilkan hubungan yang tidak signifikan dengan nilai korelasi (r) 0,338; dan tingkat signifikan 0,114. Laporan penelitian Ni'am $d k k$. (2012) menyatakan bahwa hubungan bobot badan dengan tinggi pundak sangat kuat dan signifikan dengan nilai korelasi (r) 0,65 dan 0,58. Hal ini menunjukkan bahwa hubungan antara tinggi pundak dengan bobot badan semakin erat seiring dengan bertambahnya umur. Bertambahnya bobot badan diikuti dengan bertambahnya tinggi pundak seiring dengan bertambahnya umur sapi. Pertumbuhan biasanya dimulai perlahan-lahan, kemudian berlangsung lebih cepat, selanjutnya berangsur-angsur menurun atau melambat dan berhenti setelah mencapai dewasa tubuh.

\subsection{Korelasi Bobot Badan Dengan Skor Kodisi Tubuh Sapi Bali Betina} Pada Umur 4,5 Tahun dan 5,5 Tahun

Hasil penelitian menunjukan bahwa terdapat korelasi yang sangat signifikan antara bobot badan dengan skor kondisi tubuh ternak Sapi Bali betina pada umur 4,5 tahun dan 5,5 tahun (Tabel 4).

Tabel.4. Korelasi antara bobot dengan skor kondisi tubuh ternak Sapi Bali pada umur 4,5 tahun dan 5,5 tahun yang dipotong pada RPH Kota Kefamenanu.

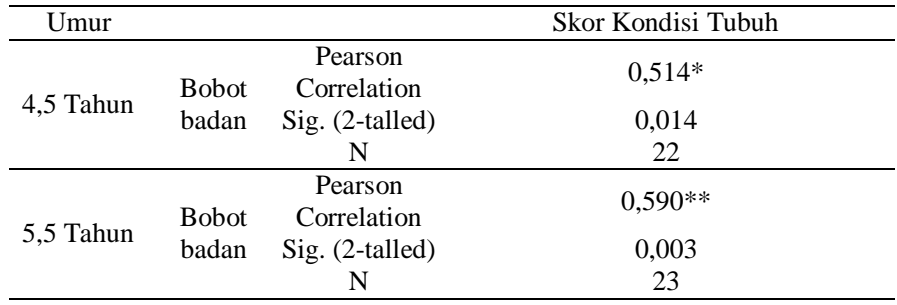

Hasil analisis korelasi antara bobot badan dengan skor kondisi tubuh menghasilkan hubungan yang signifikan dengan nilai korelasi (r) 0,514, dan tingkat signifikan 0,014 dan pada umur 5,5 tahun menghasilkan hubungan yang sangat signifikan dengan nilai korelasi (r) 0,590; dan tingkat signifikan 0,003. Hal ini menunjukkan bahwa adanya hubungan sangat kuat dan positif antara bobot badan dan skor kondisi tubuh. Laporan penelitian Ambar dkk. (2016) menyatakan bahwa hubungan bobot badan dengan skor kondisi tubuh menunjukkan hasil yang sangat signifikan dengan nilai korelasi sebesar (r) sebesar 1,000. Hal ini menunjukkan bahwa semakin tinggi bobot badan, maka semakin baik pula skor kondisi tubuh ternak dan tingkat harga jual yang didapat makin meningkat.

Hal ini sesuai pendapat Muhibbah (2007) yang menyatakan bahwa sapi yang memiliki kondisi gemuk dan mempunyai bobot potong yang terbesar memperlihatkan adanya kecenderungan kenaikan bobot badan dengan meningkatnya kondisi tubuh ternak. Sapi yang semakin gemuk akan memperlihatkan bobot potong yang semakin berat.

Banyak faktor yang menyebabkan bobot sapi menjadi berbeda-beda seperti kondisi wilayah (lingkungan), manajemen pemeliharaan, pakan dan kondisi ternak. Sesuai dengan pernyataan Muhibbah (2007) bahwa Indonesia merupakan negara yang memiliki kondisi wilayah yang beragam menyebabkan sistem pemeliharaan yang dilaksanakan berbeda-beda tergantung potens wilayah tersebut. Perbedaan penggunaan bangsa atau tipe ternak serta pakan yang digunakan akan menyebabkan bobot hidup yang dicapai juga berbeda-beda meskipun ukuran kerangka ternak relatif sama. Perbedaan sistem manajemen, penggunaan pakan dan bangsa ternak akan mengakibatkan adanya keragaman kondisi ternak. Di lapangan, sapi dijual berdasarkan bobot badan bukan berdasarkan kondisi tubuh. Kondisi tubuh memang diperhatikan, namun hanya sebagai pembantu dalam menduga bobot karkas yang akan didapatkan nantinya Sehingga, pengamatan skor kondisi tubuh lebih baik digunakan untuk pembelian bakalan. Sesuai dengan pernyataan Field \& Taylor (2002) yang menyatakan bahwa penentuan frame size dapat ditentukan berdasarkan nilai parameter tubuh ternak tersebut.

\section{Simpulan}

Dari uraian diatas dapat disimpulkan bahwa terdapat variasi bobot badan dan ukuran linear tubuh serta skor kondisi tubuh induk Sapi Bali yang dipotong di RPH Kota Kefamenanu, panjang badan memiliki korelasi yang lemah atau tidak signifikan dengan bobot badan pada umur 4,5 tahun dan 5,5 tahun, dan tinggi pundak pada umur 5,5 tahun, sebaliknya lingkar dada dan skor kondis tubuh ternak pada kedua kelompok umur memiliki hubungan yang sangat signifikan terhadap bobot badan.Lingkar dada memiliki keeratan yang lebih baik dengan bobot badan ternak Sapi Bali.

\section{Pustaka}

Akdon. 2013. Rumus dan Data dalam Analisis .Statistika. Bandung : Alfabeta.

Ambar. 2016. Hubungan Antara Kondisi Tubuh Dan Bobot Badan Dengan Harga Jual Sapi Pasundan.

Batan. IW. 2006. Sapi Bali dan Penyakitnya. Denpasar: Fakultas Kedokteran Hewan Universitas Udayana.

Djagra. I.B., I.G.N.R. Haryana, I.G.M. Putra, I.B. Mantra, dan A.A. Oka. 2002. Ukuran standar tubuh sapi Bali bibit. Laporan Hasil Penelitian Kerjasama Bappeda Propinsi Bali dengan Fakultas Peternakan Universitas Udayana, Denpasar.

Erwinda. A. A. 2012. Produktivitas Ternak Kerbau Lumpur (Swamp Buffalo) Pada Beberapa Tingkat Umur Di Nagari Languang Kecamatan Rao Utara Kabupaten Pasaman. Fakultas Peternakan Universitas Andalas. Padang.

Field. T. G., dan Taylor, R.E. 2002. Beef Production Management and Decisions [Online]. (diakses 27 Juli 2016, jam 15.35 WIB).

Harmini R. Winandi A, Juniar A. 2011. Model dinamis sistem ketersediaan daging sapi nasional. Ekonomi Pembangunan 12.

Kadarsih. S. 2003. Peranan Ukuran Tubuh Terhadap Bobot Badan Sapi Bali di Provinsi Bengkulu. Jurnal Penelitian UNIB, Vol. 9 (1) : 45-48. 
Muhibbah. 2007. Parameter Tubuh dan Sifat-Sifat Karkas Sapi Potong pada Kondisi Tubuh yang Berbeda. IPB. Bogor.

Ni'am. H. U. M., A. Purnomoadi dan S. Dartosukarno. 2012. Hubungan antara Ukuran-ukuran Tubuh dengan Bobot Badan Sapi Bali Betina pada Berbagai Kelompok Umur. Animal Agriculture Journal. 1: 541-556.

Rutter L. Engstrom D, Hand R. 2000. Body Condition: Implications for managing beef cows.

Siregar. S. B. 2008. Penggemukan Sapi Edisi Revisi. Penebar Swadaya, Jakarta. Soeparno. 2005. Ilmu dan Teknologi Daging. Yogyakarta: Gadjah Mada University Prees.

Sudarmono. A.S dan Bambang Sugeng.Y.2008.Sapi Potong. Penebar Swadaya. Jakarta.

Sugiyono. 2000. Statistik untuk Penelitian (cetakan ke 3). Bandung: Alfabeta.

Sugeng. B. Y. 2003. Sapi Potong. Penebar Swadaya. Jakarta.

Torell R. Bruce B, Kvasnicka B. 2003. Methods of Determining Age of Cattle. Ken Conley, Gund Research and Demonstration Ranch Manager. pp: 1-3.

Yusuf. M. 2004. Hubungan Ukuran Tubuh Dengan Bobot Badan Sapi Bali di Daerah Bima NTB. Fakultas Peternakan Universitas Gadja Mada. Yogyakarta. 